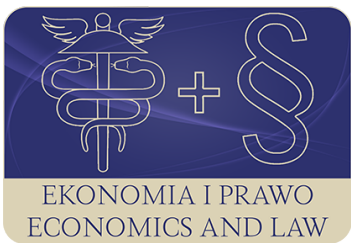

EKONOMIA I PRAWO. ECONOMICS AND LAW

Volume 20, Issue 3, September 2021

p-ISSN 1898-2255, e-ISSN 2392-1625

www.economicsandlaw.pl

EKONOMIA I PRAWO
ECONOMICS AND LAW

ORIGINAL ARTICLE

received 07.10.2020; revised 10.09.2021; accepted 30.09.2021

Citation: Szczepkowska-Flis, A., \& Kozłowska, A. (2021). Eastern enlargement: analysis of development processes in the EU15 in the context of creative destruction. Ekonomia i Prawo. Economics and Law, 20(3), 659-675. https://doi.org/10.12775/EiP.2021.039.

\title{
Eastern enlargement: analysis of development processes in the EU15 in the context of creative destruction
}

\author{
AGNIESZKA SZCZEPKOWSKA-FLIS \\ corresponding author \\ Kazimierz Wielki University in Bydgoszcz, Institute of Law and Economics, Department \\ of Economics, pl. Weyssenhoffa 11, 85-072, Bydgoszcz, Poland \\ ๑agawik.flis@op.pl \\ orcid.org/0000-0003-3946-426X \\ ANNA KOZEOWSKA \\ Poznań University of Economics and Business, Institute of Economics, Department \\ of Microeconomics, Poland \\ ๑anna.kozlowska@ue.poznan.pl \\ (D) orcid.org/0000-0002-2527-3641
}

\begin{abstract}
Motivation: Studies on the impact of the Eastern enlargement on economies of the EU15 indicate that the new member states could not be a significant engine for development processes. However, this does not exclude that the Eastern enlargement and acceding countries could have a significant impact on the mechanisms of the development of the EU15. If we consider Eastern enlargement as a Schumpeterian innovation, its longterm effects should be evident in the way creative destruction affects economic development.

Aim: The aim of the study was to determine the impact of the Eastern enlargement on the economic development of the EU15 in the context of creative destruction. In particular, the aim of the empirical analyzes was to determine whether and to what extent

the enlargement of the EU was a factor modifying the impact of creative destruction on the development of "old" members countries, and to identify the role of the new member states in these processes.
\end{abstract}


Results: Econometric analysis confirmed that creative destruction influenced economic development in the EU15, and that Eastern enlargement was a factor modifying the re-

lationship between creation, destruction, and the rate of change of GDP per capita.

The Eastern enlargement has mobilized two opposing forces. The "internal" force resulting from market selection in the EU15, which after 2004 became an active component of creative destruction, contributing however to a lower rate of change in GDP per capita. The "external" force, related to the mechanism of transmission of impulses within the grouping: synergy effects from destruction in new member countries were a catalyst for the development processes of the EU15, and synergy effects from creation were inhibitors for these processes. In the context of our research the "development leaders" can be considered the largest beneficiaries of Eastern enlargement in the EU15.

Keywords: creative destruction; eastern enlargement; economic development JEL: B15; F02; O10

\section{Introduction}

The enlargement of the European Union from 15 to 25 member states in 2004, as well as the accession of Bulgaria and Romania in 2007 and the entry of Croatia in mid 2013 significantly changed economic picture of this regional integration block (Pawlas, 2016). The so-called "Eastern enlargement" caused a significant increase in internal diversity of the EU (Pawlas, 2016, p. 81) in terms of economic, political and social sphere (Prisecaru, 2017; Proniewski \& Zielińska, 2019; Riedel, 2018; Zielińska-Głębocka, 1999). Although macroeconomic growth in the accession countries (CEEC) has been faster than in the EU, differences in development levels remain significant (Brück et al., p. 189; Ionescu, 2013). Financial and economic crisis 2008+ and differentiated pace of integration deepening ("two-speed Europe") additionally complicated economic and institutional situation of the EU (Pawlas, 2016; Riedel, 2018), which makes the issue of EU enlargement still valid, and the assessment of its effects remains an open question.

The research presented in the article is in line with the current work on the effects of EU enlargement on the economies of "old" member countries (EU15). In most works to date, the consequences of "enlargement shock" (Kohler, 2004, p. 865) for economic growth and development were analyzed in the context of classic effects resulting from the common market. In these studies, trade, capital flows, mainly foreign direct investment (FDI), and labor flows were the basic channels of transmission of pro-development impulses. In the paper we propose an alternative approach in which the Schumpeter's theory of economic development and its key mechanism of creative destruction provide the theoretical framework for the analysis of the effects of EU enlargement.

According to Schumpeter's (1960) theory, the source of development processes is innovation ${ }^{1}$, while creative destruction is the mechanism responsible for

\footnotetext{
1 The Schumpeter's definition of innovation includes both the introduction of a new
} 
moving the economy to higher growth paths. Schumpeter's mechanism of creative destruction consists of two inseparable phenomena: formation of qualitatively different, new elements of the economic system - creation; elimination of old, ineffective elements of the economic system - destruction. The consequence of creative destruction is the reallocation of production factors from less to more efficient uses, i.e., a change in the economic structure combined with an improvement in efficiency.

The central point of Schumpeter's theory is an economy in which pro-development impulses of an exclusively endogenous nature are transferred from the micro to the macroeconomic level. Such a perspective can be justified in a situation when economies are relatively autonomous systems. In international integration economies lose their "expressiveness" (Godziszewski, 2004, p. 280) and become interconnected in a wider system in which development processes take place not only inside but also beyond the borders of the countries. However, this does not exclude the possibility of applying Schumpeter's concept for the analysis of the economic development of the EU because in the integration processes one can find some analogies to the mechanisms underlying Schumpeter's development.

One of these analogies, key from the point of view of our research, can be found in the process of integration widening. According to Schumpeter (1960) and evolutionary economists, every innovation is ex definitione a source of new heterogeneity in the economic system (Fagerberg, 2003, pp. 125-159). In this context, enlarging the EU with new countries with different economic potential (Vahalík \& Staníčková, 2014, pp. 83-92) can be seen as a kind of innovation. Has this innovation provided, according to Schumpeter's concept, "fuel" for the processes of economic development through creative destruction in the EU15? This question can be considered as our basic research problem, however, unlike earlier works on Eastern enlargement effects for UE15, we do not measure the benefits of extending the common market nor identify their sources. We focus on the mechanism of creative destruction, treating it as a "carrier" of pro-development changes within and between EU countries. Determining whether and to what extent EU enlargement was a factor modifying the impact of creative destruction on the development of the EU15 and identifying the role of the new member states in these processes is the aim of the research undertaken in this paper.

In the study we modified the original concept of Schumpeter in terms of the structure of the analyzed economic system and we introduced multi-directional transmission of pro-development impulses. The key to recognizing the impact of the Eastern enlargement on the development processes of the EU15 countries was to take into account the potential synergy effects occurring within the EU structure. Moreover, taking into account the macroeconomic perspec-

commodity or the use of a new production method, as well as the creation of a new market, the acquisition of a new source of raw materials or semi-finished products or conducting a new organization of an industry (Schumpeter, 1939, p. 7; 1960, pp. 94-95). 
tive of the analyzes, we redefined the concepts of creation and destruction. In our research they do not mean literally creating and destroying economic structures and their elements (sectors, industries), but changing their shares in economic systems.

Our approach to the analysis of the EU enlargement effects on the "old" member countries in the context of creative destruction is not in opposition to the analyzes carried out so far but is an extension which provides a new perspective in the discussion on the future of Europe.

\section{Literature review}

Most of the works on the impact of the Eastern enlargement on economic growth and development of the EU15 were prepared before 2004. Later the researchers' attention was rather focused on issues related to macroeconomic stabilization and convergence processes (European Commission, 2006; 2009; Razić $\&$ Kasumović, 2019). According to some authors, in view of the low economic potential of the new member states ${ }^{2}$ and the distance in development measured by GDP per capita, the key issue in studying the effects of EU enlargement should be to determine to what extent marginal, as expected (RWI, 2000, p. 7 ), benefits of extending the common market will exceed the costs of burdening the budget and structural adjustments (Kohler, 2004, p. 866; Nuroglu \& Kurtagić, 2012, p. 60). Such a perspective was reflected only in a few studies, the authors of which, taking into account the direct budgetary cost of enlargement, estimated the net benefits for the prosperity of the EU15 (Baldwin et al., 1997; European Commission, 2006; 2009; Kohler, 2004) ${ }^{3}$. The dominant focus on the benefits of extending the common market may suggest, however, that the costs of enlargement at the level of $0.13-0.18 \%$ of GDP (Baldwin et al., 1997; Breuss, 1999) were considered insignificant for the assessment of the effects of the "enlargement shock" (European Commission, 2001, p. 26; Havlik, 2001, p. 12).

The economic consequences of the enlargement of the common market for economic growth of the EU15 and individual countries were analyzed in the context of classic effects related to the flow of goods and services and production factors. In modeling the enlargement gains, the demand/supply effects generated by trade, FDI and labor migration were seen as the main channels of impulse transmission (Baas \& Brücker, 2011; European Commission, 2006; 2009). Their scale and effects on economic growth were a function of inter-sectoral linkages. Technological aspects of trade, foreign direct investment, as well as effects resulting from competitive pressure (e.g. reallocation of resources due

2 The economic potential of CEEC was estimated at 5\% of the GDP of "old" member countries (European Commission, 2001, p. 35; Nuroglu \& Kurtagić, 2012, p. 42; Verheugen, 2002, p. 3).

3 Some authors have considered other indirect enlargement costs related to structural adjustments in the labour market (European Commission, 2006; Lammers, 2004). 
to market selection and mark-up effects) and convergence processes, although considered by some authors (Antimiani \& Costantini, 2010; Curran \& Zignago, 2012; European Commission, 2001; Havlik, 2001; Rojec \& Damijan, 2008), were marginalized.

The basic conclusion from the analyzes is the statement that the benefits of the EU enlargement were mutual, with smaller pro-development effects recorded for the old countries ${ }^{4}$. Taking into account the integration of two blocs of countries with significantly different economic potential, this result was expected and confirmed the opinion that although the CEEC were a "bonanza" for Western European business (Baldwin, 1995, p. 475; Baldwin et al., 1997, p. 127) they could not be a significant engine for the development of the EU15 (Barysch, 2006, p. 2).

Results of the analyses conducted at the country level were mixed. For example, in some countries called Cohesion's Funds Countries direct budget costs outweighed the potential benefits, creating negative net effects. This group of countries included: Greece, Spain, Portugal, and Ireland (European Commission, 2009, p. 25; Kohler, 2004, p. 886; Lammers, 2004, p. 138). The greatest positive enlargement effects were noted for those EU15 countries that were characterized by "proximity" to the new member states and intense economic cooperation with them (trade links and FDI flows) (e.g. Austria and Germany) (Breuss, 1999; European Commission, 2001; Havlik, 2001; Kohler, 2004; Lejour et al., 2001). These effects were higher in the before accession period, especially with regard to FDI (Barysch, 2006, p. 2). This result may suggest that from the point of view of the "old" member countries, the benefits of the strictly institutional aspect of integration (integration widening) in the conditions of already existing economic ties with acceding Member Countries are subject to a specific law of diminishing returns.

The results of the research also indicate that due to the convergence processes and structural changes at the level of industries/sectors, the long-run enlargement effects for the EU15 could be higher than the short-run demand and supply impulses generated as part of inter-sectoral connections (Bchir et al., 2003; European Commission, 2001; 2009; Lammers, 2004; RWI, 2000). According to Nahuis (2004), Eastern enlargement generated shocks that were not only different for different countries but were also highly asymmetric across industries: some industries have declined whereas others had the potential to benefit from enlargement. In other words, different industries were affected differently, and on the industry level losers were inevitable (Lejour et al., 2001). An important role in this process was played by the flexibility of reallocation of production factors (Nahuis, 2004) and degree of competition (European Commission, 2001). According to European Commission (2001), for some sec-

${ }^{4}$ The benefits estimated for the entire EU15, regardless of the procedure used and the time scope of the study, did not exceed 1\% of GDP (European Commission, 2006, p. 25; 2009, p. 25). For comparison, the benefits for the "new" countries were estimated at the level of 1.5-18.8\% GDP (European Commission, 2009, p. 25). 
tors of the EU15 economies, enlargement could lead to a higher degree of competition due to the removal of trade barriers. It could lead not only to positive allocation effects, via reduction in mark-up levels, but also to positive accumulation effects, via the decline of X-inefficiency prompted by greater competition and/or via spillover effects on the EU15 TFP growth coming from the higher TFP growth in the acceding countries. This increase in competition/efficiency or allocation gains puts the economy on a higher potential level and leads to a more significant "transitory" increase in GDP growth. Interpretation of these observations in the context of Schumpeter's theory of economic development means that in a properly functioning open and integrated market economy the most productive economic sectors eventually expand (creative process), and the less profitable ones contract (destructive process) in terms of both their output and the inputs used (European Commission, 2009). The final consequence of these changes is the transfer of the economy to higher growth paths (European Commission, 2001; Kozłowska, 2010).

Numerous empirical studies conducted in the area of efficiency, industry structure and the labor market have confirmed the positive impact of creative destruction on changes in productivity and economic development (Bernanke, 1983; Montgomery \& Wascher, 1988). They also showed that the conditions under which development processes take place may cause the form and effects of creative destruction to differ from the theoretical construction of Schumpeter (Kozłowska, 2010, p. 70). This statement is partially confirmed in works on the role of creative destruction in development processes taking place under the conditions of European integration. Research carried out for the period 1996-2011 for EU member states (Kozłowska \& Szczepkowska-Flis, 2014a) revealed that while creation stimulated development processes measured by changes in real GDP per capita and labor productivity, selection mechanisms weakened them. At the same time, it was shown that the greater the intensity of creative destruction in a given member state, the greater its share in shaping the economic development of EU. The results of analyzes carried out for 11 countries of Central and Eastern Europe (new EU members) for the years 1996-2012 (Kozłowska \& Szczepkowska-Flis, 2014b) indicate, in turn, that accession to the EU was a trigger of a positive impact of creation on the economic development of new member states, however, it did not change the negative impact of selection on these processes, observed also before accession. Moreover, on the basis of research carried out for $28 \mathrm{EU}$ member states in the years 1999-2018 (Szczepkowska-Flis \& Kozłowska, 2020), it was found that under the conditions of differentiated integration ("two speed Europe"), the economic development of the EU member states depended on the creation processes that came both from their economic systems as well as from the economic systems of other EU countries (synergy effects). The strength of this impact did not depend on the degree of institutional integration but was a function of differences in the economic dimension: the greater the differences in the level of economic 
development of the member states, the greater the probability of negative synergy effects.

These results indicate the validity of our research concept. The research on the consequences of Eastern enlargement conducted from the perspective of "old" member countries, despite the internal transformations of the EU, was not continued, therefore the research problem undertaken in this paper seems even more interesting.

\section{Methods}

To achieve the aim of the research the econometric analysis for 15 "old" EU member countries in the years 1999-2018 was conducted. The subject of the research was the impact of creative destruction on economic development in the EU15 countries during EU enlargement. The study used annual data published in the EUROSTAT, UNCTAD and World Bank statistical databases. Thus, the basic explained variable was the economic development of individual "old" member countries, while the explanatory variables were the processes of creative destruction taking place in their economic systems. Modeling the relationship between these categories additional variables were included reflecting: the period before and after Eastern enlargement and synergy effects from the environment created by the new member states. These variables relate directly to the research objective and express the institutional and economic aspects of EU enlargement. Although the Eastern enlargement of the EU was a gradual process, its institutional dimension is identified in this study with 2004. The economic aspect is seen as an additional space created within the common market for the activity of creative destruction. In this context, its environment becomes an active "participant" in creation and destruction in each member state. In this study, the synergy effects express the joint impact of creative destruction taking place in the "old" member countries and their new environment, which is subject to changes resulting from the different pace of deepening the integration of new member states. Moreover, the study takes into account the differentiation in the level of development of the "old" member countries in relation to the new ones, assuming that this is a factor influencing the strength of the synergy effects.

The growth rate of real GDP per capita (variable gpc) was used as a measure of economic development. Evometrics (evolutionary econometrics) was used to estimate the processes of creative destruction (Andersen, 2004). This method enables the decomposition of creative destruction into a selection effect, which is a measure of destruction, and an innovation effect, which is a measure of creation. The values of the innovation effect (variable EI) and the selection effect (variable ES) in each of the analyzed countries (j) were estimated based on the real gross value added (VA) produced in 19 sections (i), compliant with the NACE Rev. 2, of each economy according to the formula: 


$$
E S_{j t}+E I_{j t}=\frac{\sum_{i} u_{i j t}\left(w_{i j t}-w_{j t}\right)^{2}}{w_{j t}}+\frac{\sum_{i} u_{i j t} w_{i j t} \Delta w_{i j t}}{w_{j t}},
$$

where:

$$
\begin{aligned}
& w_{i j t}=\frac{V A_{i j t}}{V A_{i j t-1}}-\text { absolute reproduction coefficient of section } i \text { in country } j \\
& \Delta w_{i j t}-\text { change of absolute reproduction coefficient of section } i \text { in country } j \\
& \text { in year } t \text {; } \\
& u_{i j t}-\text { share of section } i \text { in generating the gross value added of country } j \\
& \text { in year } t \text {; } \\
& w_{j \mathrm{t}}=\sum_{i} u_{i j \mathrm{t}} w_{i j \mathrm{t}} \text { - weighted reproduction coefficient of country } j \text { in year } t \text {. }
\end{aligned}
$$

The selection and innovation effects are measures of creative destruction in the economy. A higher value of the innovation effect reflects stronger creation processes, while a higher selection effect expresses a greater intensity of destruction processes.

Two synergy effects were distinguished: taking into account the processes of creative destruction in the economies of the new member states that joined the euro area (variables KEI_l, KES_l) and taking into account the processes of creative destruction in the economies of new member states that remained outside the monetary union (variables KEI_2, KES_2). Synergy effects were expressed as the interaction of variables:

$$
\begin{aligned}
& K E I_{j t}=E I_{j t} \times \overline{E I_{t}}, \\
& K E S_{j t}=E S_{j t} \times \overline{E S_{t}},
\end{aligned}
$$

where: $\overline{E I_{t}}, \overline{E S_{t}}$ are the weighted averages of innovation and selection effects estimated for year $t$ for each of the new EU members.

Two binary variables: $D 1$ and $D 2$ were included in the regression equations. The variable Dl was assigned the value 0 for the years 1999-2003 (pre-enlargement period), and the value 1 for the years 2004-2018 (post-enlargement period). The variable D2 expresses the differentiation in the level of economic development in the group of "old" member states as compared to the new members of the EU. The distance in economic development $\left(D R_{j}\right)$ between "old" member state $j$ and a group of new member states in a given year was calculated as the difference between GDP per capita in the old country $j$ in year $t$ and the average level of GDP per capita estimated for the group of new member states in year $t$. If $D R_{j}$ in a given year exceeded the mean distance $\left(D R_{\text {mean }}\right)$ calculated for the EU15, the variable D2 was assigned a value of 1 , otherwise the value of 0: if $D R_{j t} / D R_{\text {mean }}>1$ then $D 2=1$, if $D R_{j t} / D R_{\text {mean }}<1$ then $D 2=0$. Countries for which 
the variable $D 2$ was equal to 1 in the entire research period are referred to as development leaders.

Due to the two-dimensional nature of the obtained data the panel regressions were used. The differences in the countries included in the study, visible in the descriptive statistics, suggested that the specificity of countries may affect the results of panel regression estimation. Taking into account the existing differentiation of countries, fixed effects panel regression models were estimated (Davidson \& MacKinnon, 1999, pp. 297-298):

$$
Y_{i t}=C+\beta_{i} X_{i t}+\delta_{i}+\varepsilon_{i t},
$$

where:

$Y_{\text {it }}$ - dependent variable;

$X_{\text {it }}$ - independent variable;

$\beta_{i}$ - regression coefficient;

$\delta_{i}$ - fixed effects;

C- constant;

$\varepsilon_{i t}$ - residuals.

The Levin, Lin and Chu panel unit root test was used to check the stationarity of the series (Kennedy, 1998, pp. 268-269, 283-286). For each of the regression equations, a test of redundant fixed effects was performed using the $\mathrm{F}$ statistic (Greene, 2003, p. 289). The normality of the residuals was tested using the Lilliefors test (Abdi \& Molin, 2007). The regression parameters were estimated using White's heteroskedasticity and autocorrelation consistent standard errors (Kennedy, 1998, p. 121; Wooldridge, 2001, p. 57; 2002, pp. 249-253). The statistical significance of the regression parameter estimates was set at the level of $\alpha=0.05$.

\section{Results}

The unit root tests indicated that all variables used in the study were stationary. The results of the econometric analysis of panel regression equations describing the impact of creative destruction on the economic development of the EU15 are presented in Tables 1-4.

The results of the regression equation taking into account the direct division of the analyzed period into pre- and post-enlargement (binary variable $\mathrm{Dl}$ ) (Table 1) showed that:

- the creation processes had a positive impact on the rate of changes in GDP per capita, and there were no statistically significant differences in this impact in both periods;

- selection was a significant factor determining the rate of changes in GDP per capita only in the post-enlargement period, and its negative impact on the economic development was inconsistent with expectations.

The results confirm that the EU enlargement in the institutional dimension was a factor modifying the impact of creative destruction on the economic devel- 
opment of the EU15. This statement concerns the role of individual components of creative destruction in shaping development processes: while the role of creation as a catalyst for these processes has not changed, the selection, initially passive, after the enlargement of the EU weakened development processes. This result suggests that economic integration and expansion of the common market do not guarantee a "model" course of development processes in the EU15, consistent with the Schumpeter's theory. On the one hand, economic integration removes barriers to the spread of creative destruction, on the other hand, as Tinbergen emphasizes (1965, p. 57, as cited in Midera, 2004, p. 202), can create new institutional solutions that disturb the proper operation of selection.

The model with the synergy effects (Table 2) indicate, however, that the sources of these modifications may come not only from institutional solutions, but also from economic ties that arose/developed within the extended common market (economic dimension of the EU enlargement). The results of the estimation revealed that the processes of creation and destruction in the economies of the new member states modified the strength of the relationship between the variables EI, ES and gpc in the EU15 - synergy effects weakened the pro-development impact of creation and the anti-development effect of destruction. This conclusion refers only to the synergy effects resulting from participation in the common market, and not generated within new EU countries - euro area members (regression coefficients for the variables KEI_l and KES_l were not statistically significant).

Taking into account that integration transforms economies into elements of one system, the effects of creative destruction in the economy reflect the processes of creation and destruction in which all participants of the common market take part (companies, industries, sectors, other national economies). In this context, the asymmetry noted in the synergy effects may reflect the result of "competitive struggle" taking place at the sectoral level (Nahuis, 2004), the final impact of which on the economic development of the EU15 may, as some authors point out (European Commission, 2009), depend on the scale and structure of intersectoral economic ties.

The analyzes were supplemented with the estimation of two regression models taking into account the relative differentiation in the level of development in the EU15 (binary variable D2). In this case, it was necessary to estimate two regression equations, in which the analysis of development processes was carried out separately: with the synergy effects from the new EU countries outside the euro area (Table 3) and with the synergy effects from the new EU countries inside the euro area (Table 4). The results of these models were interpreted jointly. The results revealed:

- the synergy effects of creation in both groups of new countries lowered the positive impact of creation in the EU15 on their economic development. In the case of synergy effects from the economies of new non-euro area countries, the strength of this impact was related to the D2 variable - this impact was weaker in the "development leaders"; 
- only the new countries outside the euro area were the source of significant synergy effects due to selection, and the positive impact of these effects on the relationship between ES and gpc in the EU15 was stronger in "development leaders".

It can be concluded that the relative advantage in the level of development of the "old" member countries was a kind of shield against the negative synergy effects arising from creation. At the same time, it offered better possibility to enjoy the benefits coming indirectly from the selection mechanisms operating in the economies of the new member states outside the euro area. In other words, the "development leaders" (Austria, Finland, Netherlands, Luxemburg, Germany, Denmark, Sweden) can, in the context of this research, be considered the largest beneficiaries of Eastern Enlargement in the EU15.

\section{Conclusion}

Econometric analysis confirmed that the mechanisms of creative destruction influenced economic development in the EU15, and Eastern enlargement was a factor modifying the relationship between creation, destruction and the rate of change of GDP per capita. In the pre-enlargement period, creation stimulated the economic development of the EU15, but its pro-development impact was not supported by destruction (market selection at the sector level played a passive role in this period). If, according to Schumpeter's theory, the interaction of both components of creative destruction is the condition for achieving the optimal growth path, the result suggests that the economies of the EU15 did not use the development potential which, at least in assumptions, was ensured by the common market and free reallocation of resources. Can the Eastern enlargement be then considered as a factor that ensured the appropriate economic dynamism for the EU15? In the light of our results, it is not possible to give an unequivocal answer to this question, because the enlargement of the EU has mobilized two opposing forces:

- "internal", due to market selection in the EU15, which, admittedly, became an active component of creative destruction, but its increase lowered the rate of changes in GDP per capita;

- "external", related to the mechanism of transmission of impulses within the grouping - synergy effects from destruction coming from the new EU countries were a catalyst for the development of the EU15, and synergy effects from creation were inhibitors for this process.

Taking into account that integrated economies become elements of a wider system, the asymmetry noted in the synergy effects seems to be a natural consequence of the competition processes within the grouping, the effects of which are revealed in individual member states. The final effect of creative destruction for economic development of the EU should be positive, but the shares of individual "old" member countries in the distribution of the benefits of enlargement are not equal and depend on the relative level of their development. 
Moreover, while the expansion of the common market and the emergence of new economic ties modified the influence of creation and destruction on economic development of the EU15, further tightening of cooperation within the common currency area did not play an important role in this process. This may suggest that the impulse from the integration widening was stronger for the dynamics of the EU15 than the impulse coming from integration deepening.

\section{References}

Abdi, H., \& Molin, P. (2007). Lilliefors/Van Soest's test of normality. In N.J. Salkind (Ed.), Encyclopedia of measurement and statistics (pp. 1-10). SAGE.

Andersen, E.S. (2004). Evolutionary econometrics: from Joseph Schumpeter's failed econometrics to George Price's general evometrics and beyond [Paper presentation]. The Third Workshop on the Economic Transformation of Europe (ETE). Sophia-Antipolis, France.

Antimiani, A., \& Costantini, V. (2010). Trade performances and technology in the enlarged European Union. Journal of Economic Studies, 40(3), 355389. https://doi.org/10.1108/01443581311283961.

Baas, T., \& Brücker, H. (2011). EU eastern enlargement: the benefits from integration and free labour movement. CESifo DICE Report, 9(2), 44-51.

Baldwin, R.E. (1995). The eastern enlargement of the European Union. European Economic Review, 39(3-4), 474-481. https://doi. org/10.1016/0014-2921(94)00053-3.

Baldwin, R.E., Francois, J.F., Portes, R., Rodrik, D., \& Székely, I.P. (1997). The costs and benefits of eastern enlargement: the impact on the EU and central Europe. Economic Policy, 12(24), 125-176. https:// doi.org/10.1111/1468-0327.00018.

Barysch, K. (2006). East versus west: the EU economy after enlargement. Retrieved 25.06.2020 from https://www.cer.eu/sites/default/files/publications/attachments/pdf/2011/essay_eastvswest_jan06-2088.pdf.

Bchir, H., Fontagné, L., \& Zanghieri, P. (2003). The impact of EU enlargement on member states: a CGE approach. CEPII Working Paper, 10, 1-54.

Bernanke, B.S. (1983). On the sources of labour productivity variation in U.S. manufacturing, 1947-1980. Review of Economics and Statistics, 65(2), 214224. https://doi.org/10.2307/1924487.

Breuss, F. (1999). Costs and benefits of EU enlargement in model simulations. IEF Working Paper, 33, 1-44.

Brück, T., Brücker, H., Engerer, H., von Hirschhausen, C., Schrooten,M., Schumacher, D., Thiessen, U., \& Trabold, H. (2004). The eastern enlargement of the European Union: clear challenges, unjustified fears. Economic Bulletin, 41(6), 189-198. https://doi.org/10.1007/s10160-004-0274-x.

Curran, L., \& Zignago, S. (2012). EU enlargement and the evolution of European production networks. Research in International Business and Finance, 26(2), 240-257. https://doi.org/10.1016/j.ribaf.2011.12.002. 
Davidson, J.G., \& MacKinnon, J.G. (1999). Foundations of econometrics. Retrieved 25.06.2020 from https://russell-davidson.arts.mcgill.ca/e468/ Ectsbook.pdf.

European Commission. (2001). The economic impact of enlargement. Retrieved 15.06.2020 from https://ec.europa.eu/archives/economy_finance/ publications/archives/pdf/publication1583_en.pdf.

European Commission. (2006). Enlargement: two years after: an economic evaluation. Retrieved 15.06.2020 from https://ec.europa.eu/economy_finance/ publications/pages/publication7548_en.pdf.

European Commission. (2009). Five years of an enlarged EU: economic achievement and challenges. Retrieved 15.06.2020 from https://ec.europa.eu/ economy_finance/publications/pages/publicationl4078_en.pdf.

Fagerberg, J. (2003). Schumpeter and the revival of evolutionary economics: an appraisal of the literature. Journal of Evolutionary Economics, 13(2), 125-159. https://doi.org/10.1007/s00191-003-0144-1.

Godziszewski, B. (2004). Globalizacja a mikroekonomiczne czynniki wzrostu gospodarczego. In M. Haffer, \& W. Karaszewski (Eds.), Czynniki wzrostu gospodarczego (pp. 279-296). Uniwersytet Mikołaja Kopernika w Toruniu.

Greene, W.H. (2003). Econometric analysis. Prentice Hall.

Havlik, P. (2001). EU enlargement: economic impacts on Austria, the Czech Republic, Hungary, Poland, Slovakia and Slovenia. WIIW Research Report, 280, 1-19.

Ionescu, R. - V. (2013). EU's enlargement vs global crisis. Acta Inuversitatis Danunius: Oeconomica, 9(4), 319-331.

Kennedy, P. (1998). A guide to econometrics. MIT Press.

Kohler, W. (2004). Eastern enlargement of the EU: a comprehensive welfare assessment. Journal of Policy Modeling, 26(7), 865-888. https://doi. org/10.1016/j.jpolmod.2004.08.006.

Kozłowska, A. (2010). Ewolucja struktur gospodarczych w świetle Schumpeterowskiej koncepcji kreatywnej destrukcji. Uniwersytet Ekonomiczny w Poznaniu.

Kozłowska, A., \& Szczepkowska-Flis, A. (2014a). Aplikacja koncepcji kreatywnej destrukcji do analizy procesów rozwojowych w Unii Europejskiej. Studia i Prace Wydziatu Nauk Ekonomicznych i Zarządzania Uniwersytetu Szczecińskiego, 35(2), 109-124.

Kozłowska, A., \& Szczepkowska-Flis, A. (2014b). Rola integracji gospodarczej w kształtowaniu procesów rozwojowych: analiza w kontekście kreatywnej destrukcji. Prace Naukowe Uniwersytetu Ekonomicznego we Wroctawiu, 347, 262-27l. https://doi.org/10.15611/pn.2014.347.24.

Lammers, K. (2004). How will the enlargement affect the old members of the European Union. Intereconomics, 39(3), 132-141. https://doi. org/10.1007/bf02933580.

Lejour, A.M., \& De Mooij, R.A., \& Nahuis, R. (2001). EU enlargement: economic implications for countries and industries. CESifo Working Paper, 585, $1-32$. 
Midera, A. (2004). Koncepcje międzynarodowej integracji gospodarczej: próba klasyfikacji. Acta Universitatis Lodziensis: Folia Oeconomica, 180, 195-208.

Montgomery, E., \& Wascher, W. (1988). Creative destruction and the behaviour of productivity over the business cycle. Review of Economics and Statistics, 70(1), 168-172. https://doi.org/10.2307/1928167.

Nahuis, R. (2004). One size fits all: accession to the internal market; an industry level assessment of EU enlargement. Journal of Policy Modeling, 26(5), 571-586. https://doi.org/10.1016/j.jpolmod.2004.04.013.

Nuroglu, E., \& Kurtagić, H. (2012). Costs and benefits of the EU enlargement: the impact on the EU and SEE countries. Journal of Economic and Social Studies, 2(2), 4l-65. https://doi.org/10.14706/jecossl1223.

Pawlas, I. (2016). Economic picture of the enlarged European Union in the light of taxonomic research. In Vopava, J., Douda, V., Kratochvil, R., \& Konecki, M. (Eds.), Proceedings of MAC-EMM 2016 (pp. 75-82). MAC Prague consulting.

Prisecaru, P. (2017). Do we have or need a two speed Europe? Academic Journal of Economic Studies, 3(3), 54-61.

Proniewski, M., \& Zielińska, J.B. (2019). Innovative potential of the European Union's member states in 2017. European Research Studies Journal, 22(4), 4959. https://doi.org/10.35808/ersj/1496.

Razić, S., \& Kasumović, M. (2019). Macroeconomic stability of new member states of the European Union: fifth enlargement. Theoretical and Applied Economics, 26(618), 23-36.

Riedel, R. (2018). Zróżnicowana integracja w Europie: źródła, mechanizmy, konsekwencje. Studia Ekonomiczne: Zeszyty Naukowe Uniwersytetu Ekonomicznego w Katowicach, 352, 213-222.

Rojec, M., \& Damijan, J.P. (2008). Relocation via foreign direct investment from old to new EU member states: scale and structural dimension of the process. Structural Change and Economic Dynamics, 19(1), 53-65. https://doi. org/10.1016/j.strueco.2007.11.005.

RWI. (2000). Impact of the enlargement of the European Union on small and medium-sized enterprises in the Union. Retrieved 23.06.2020 from http://aei.pitt. edu/34856/1/A914.pdf.

Schumpeter, J.A. (1939). Business cycles: a theoretical, historical, and statistical analysis of the capitalist process. McGraw-Hill.

Schumpeter, J.A. (1960). Teoria rozwoju gospodarczego. PWN.

Szczepkowska-Flis, A. \& Kozłowska, A. (2020). Europa dwóch prędkości: ocena w kontekście kreatywnej destrukcji. In M. Geise, E. Dziawgo, \& A. Uziębło (Eds.), Stan i perspektywy rozwojowe Unii Europejskiej (pp. 97-118). Uniwersytet Kazimierza Wielkiego w Bydgoszczy.

Vahalík, B., \& Staníčková, M. (2014). Comparison of regional competitiveness index after EU enlargement in 2013. Scientific Papers of the University of Pardubice: Series D: Faculty of Economics \& Administration, 21(31), 83-92. 
Verheugen, G. (2002). Entering the final stage. [Speech]. Retrieved 25.06.2020 from https://ec.europa.eu/commission/presscorner/detail/en/ SPEECH_02_602.

Wooldridge, J.M. (2001). Econometric analysis of cross section and panel data. MIT Press.

Wooldridge, J.M. (2002). Introductory econometrics: a modern approach. South-Western Educational Publishing.

Zielińska-Głębocka, A. (1999). Dynamika Unii Europejskiej w świetle teorii integracji. Studia Europejskie, 3, 11-32.

\section{Acknowledgements}

Author contributions: authors have given an approval to the final version of the article. Authors contributed to this work equally.

Funding: this research was funded by authors' own sources.

Note: the results of this study were presented at 9th Scientific Conference: Contemporary Economic Problems 'Thirty years of transformation' (September, 16, 2020, online, Poland). 


\section{Appendix}

Table 1.

Estimation results for pre- and post-enlargement periods

\begin{tabular}{lcccc}
\hline \multicolumn{1}{c}{ Variable } & Coefficient & Standard error & t-Statistic & Probability \\
\hline constant & 0.0202 & 0.0061 & 3.3262 & 0.0010 \\
EI & 0.4777 & 0.0995 & 4.8017 & 0.0000 \\
ES & -0.0516 & 0.4056 & -0.1273 & 0.8988 \\
Dl*EI & -0.0007 & 0.1640 & -0.0045 & 0.9964 \\
Dl*ES & -0.5660 & 0.2289 & -2.4731 & 0.0139 \\
\hline \multicolumn{4}{c}{ Weighted statistics } \\
root MSE & 0.0280 & R-squared & 0.4136 \\
mean dependent variable & 0.0184 & adjusted R-squared & 0.3793 \\
S.D. dependent variable & 0.0369 & S.E. of regression & 0.0288 \\
sum squared residuals & 0.2562 & F-statistic & 12.0696 \\
D-W statistic & 0.9749 & Prob(F-statistic) & 0.0000 \\
\hline
\end{tabular}

Source: Own preparation.

Table 2.

Estimation results with synergy effects

\begin{tabular}{lrcrc}
\hline \multicolumn{1}{r}{ Variable } & Coefficient & Standard error & t-Statistic & Probability \\
\hline constant & 0.0212 & 0.0035 & 6.0987 & 0.0000 \\
EI & 0.5380 & 0.0683 & 7.8824 & 0.0000 \\
ES & -2.5548 & 0.4900 & -5.2155 & 0.0000 \\
KEI_1 & -1.0623 & 1.1796 & -0.9006 & 0.3685 \\
KES_1 & 0.6026 & 9.5304 & 0.0632 & 0.9496 \\
KEI_2 & -1.3877 & 0.6744 & -2.0577 & 0.0405 \\
KES_2 & 60.2232 & 17.5872 & 3.4243 & 0.0007 \\
\hline
\end{tabular}

\begin{tabular}{lcll}
\hline & \multicolumn{2}{c}{ Weighted statistics } & \\
root MSE & 0.0258 & R-squared & 0.5284 \\
mean dependent variable & 0.0188 & adjusted R-squared & 0.4976 \\
S.D. dependent variable & 0.0380 & S.E. of regression & 0.0266 \\
sum squared residuals & 0.2172 & F-statistic & 17.1453 \\
D-W statistic & 0.9921 & Prob(F-statistic) & 0.0000 \\
\hline
\end{tabular}

Source: Own preparation. 
Table 3.

Estimation results with synergy effects coming from new EU states - outside euro area

\begin{tabular}{lcccc}
\hline \multicolumn{1}{c}{ Variable } & Coefficient & Standard error & t-Statistic & Probability \\
\hline constant & 0.0255 & 0.0044 & 5.7520 & 0.0000 \\
EI & 0.5308 & 0.0680 & 7.8098 & 0.0000 \\
ES & -2.6570 & 0.5737 & -4.6314 & 0.0000 \\
KEI_2 & -2.2674 & 0.4253 & -5.3316 & 0.0000 \\
KES_2 & 27.8330 & 12.5636 & 2.2154 & 0.0275 \\
D2*KEI_2 & 0.6038 & 0.2990 & 2.0196 & 0.0443 \\
D2*KES_2 & 36.7723 & 15.2912 & 2.4048 & 0.0168 \\
\hline
\end{tabular}

\begin{tabular}{lcll}
\hline & \multicolumn{3}{c}{ Weighted statistics } \\
root MSE & 0.0246 & R-squared & 0.5368 \\
mean dependent variable & 0.0179 & adjusted R-squared & 0.5065 \\
S.D. dependent variable & 0.0366 & S.E. of regression & 0.0255 \\
sum squared residuals & 0.1986 & F-statistic & 17.7318 \\
D-W statistic & 1.0146 & Prob(F-statistic) & 0.0000 \\
\hline
\end{tabular}

Source: Own preparation.

Table 4.

Estimation results with synergy effects coming from new EU states - euro area members

\begin{tabular}{lrcrc}
\hline \multicolumn{1}{c}{ Variable } & Coefficient & Standard error & t-Statistic & Probability \\
\hline constant & 0.0252 & 0.0067 & 3.7514 & 0.0002 \\
EI & 0.5205 & 0.1012 & 5.1440 & 0.0000 \\
ES & -0.9803 & 0.3365 & -2.9129 & 0.0038 \\
KEI_l & -4.1564 & 0.7044 & -5.9006 & 0.0000 \\
KES_1 & -7.7136 & 17.8460 & -0.4322 & 0.6659 \\
D2*KEI_l & 1.1255 & 1.1967 & 0.9405 & 0.3477 \\
D2*KES_1 & 20.5333 & 15.3384 & 1.3387 & 0.1817 \\
\hline \multicolumn{5}{c}{ Weighted statistics } \\
root MSE & 0.0262 & R-squared \\
mean dependent variable & 0.0181 & adjusted R-squared & 0.4704 \\
S.D. dependent variable & 0.0363 & S.E. of regression & 0.4357 \\
sum squared residuals & 0.2240 & F-statistic & 0.0271 \\
D-W statistic & 1.0478 & Prob(F-statistic) & 13.5872 \\
\hline & \multicolumn{4}{c}{0.0000} \\
\hline
\end{tabular}

Source: Own preparation. 
